\title{
Designing and Manufacturing of Grain Dryer Machine using Coconut Shell Fuel as an Alternative Heat Energy
}

\author{
Dermawan $^{1, \mathrm{~b}}$, Rusdi Nur ${ }^{1,2, *, a}$, Tri Agus Susanto ${ }^{1, \mathrm{c}}$, and Amrullah ${ }^{2, \mathrm{~d}}$ \\ ${ }^{1}$ Mechanical Engineering Department, Politeknik Negeri Ujung Pandang, Jalan Perintis Kemerdekaan Km. 10 Makassar, \\ 90245, Indonesia \\ ${ }^{2}$ Center for Materials and Manufacturing, Politeknik Negeri Ujung Pandang, Jalan Perintis Kemerdekaan Km. 10 Makassar, \\ 90245, Indonesia \\ *,a rusdinur@poliupg.ac.id, bdermawan@poliupg.ac.id, triagussusanto@poliupg.ac.id, ${ }^{\mathrm{d}}$ amrullah@poliupg.ac.id
}

\begin{abstract}
Many problems in the process of drying grain with a solar heat source. One of the factors is the erratic weather, where the rainy season comes along with harvest time. To overcome these obstacles, a grain dryer was designed that uses a rotary system that is simpler and more efficient and uses coconut shells as an alternative fuel. This study aims to obtain fast and affordable grain drying results by farmers using a rotary system dryer with coconut shell fuel. The benefit of this research is to provide an alternative solution for the community in dealing with harvesting in the rainy season by reducing land for drying grain. Equipment preparation was carried out in particular by using standard equipment to cut and connect the seat frame including the use of silencers and gasoline-fueled motors as propulsion and other supporting equipment. The components of each unit of grain drying machine are assembled and tested in stages according to procedures and functions. The test results show that the use of coconut shell can reach drying temperatures faster than the use of LPG, coconut shell fuel is better at reducing the moisture content of grain than the use of LPG. Testing of coconut shell fuel is done by drying $30 \mathrm{~kg}$ of grain for 20 minutes and 15 minutes. It can be concluded that the use of coconut shell as an alternative fuel can achieve a faster drying temperature than the use of LPG fuel. The use of coconut shell fuel to dry $30 \mathrm{~kg}$ of grain and reach a moisture content of up to $12 \%$ requires an effective time of 15 minutes.
\end{abstract}

Keywords—manufacturing;grain; dryer; coconut shell; fuel

\section{Introduction}

Indonesia, is the largest agricultural country in the world, has diverse natural resources and a wide area. Indonesia is also the third largest rice producing country in Southeast Asia [1]-[3]. In general, farmers rely more on solar heat to dry grain, due to limited technology and low costs. The obstacle faced in the solar heat drying system is the unpredictable weather in Indonesia where the rainy season coincides with harvest time. This kind of drying model results in rice not being able to dry perfectly, being easily contaminated with dust and dirt when dried in the sun. Imperfect drying causes the rice produced to be less good in quality and quantity, thus it has a low market value [4], [5]. One of the requirements for good dry grain quality is having a maximum moisture content of $14 \%$. Moisture content is the amount of water content of grain expressed in percent of wet weight [3]. In a study conducted by Tamaria Panggabean with a rack-type grain dryer, it showed that the mass of evaporated grain water was higher than drying using solar energy [6]. Rice grain dryer box type is one of the effective tools for drying grain when viewed from the results of reducing water content [7]. Another study investigating the effect of air velocity and grain mass on grain drying speed, the use of a fluidized dryer showed that the higher the air velocity, the faster the drying process [8], [9]. A rotary system of grain dryer with rice husk fuel developed by Sattar Yunus [10]. This dryer can dry $50 \mathrm{~kg}$ of grain with an average time of 30 minutes. The rice dryer with a rotary dryer model developed by Hariyanto with a capacity of 2 tons with rice husk fuel can function properly with an average grain drying process of $6-7$ hours at a temperature of 60 - $65^{\circ} \mathrm{C}$ [11]. The use of coconut shells as fuel in the drum dryer type grain dryer. The results showed that the time required to dry $1 \mathrm{~kg}$ of rice grain was 3.75 minutes [12]. Although the rotary system is one of the solutions in grain drying, the rotary system dryer with a large 
capacity still has an expensive price and the fuel required is also very large. Therefore, in this research, it will be designed with the concept of Appropriate Technology (TTG) to produce a rotary system grain dryer that is simpler and more efficient with alternative fuels using coconut shell.

The purpose of this study was to obtain fast and affordable grain drying results by farmers using a rotary system dryer with coconut shell fuel. The benefit of this research is to provide an alternative solution for the community in overcoming the harvest in the rainy season with the reduced land for drying grain.

\section{Research Methodology}

The initial method carried out in this study was to identify problems in the community to overcome the harvest in the rainy season with less land to dry grain. The next method is to design and manufacture a rotary system grain dryer with coconut shell fuel with the required planning of equipment specifications (such as: height, length, width, diameter of the stirrer shaft, power of the driving motor). So that it can be determined the effective time used to dry the grain.

Equipment preparation is carried out in particular using standard equipment to cut and connect the frame of the seat including the use of reducers and gasolinefueled motors as propulsion and other supporting equipment. The components of each unit of the grain drying machine are assembled and tested in stages according to the procedures and functions. The installation of the grain drying machine test equipment is shown in Figure 1.

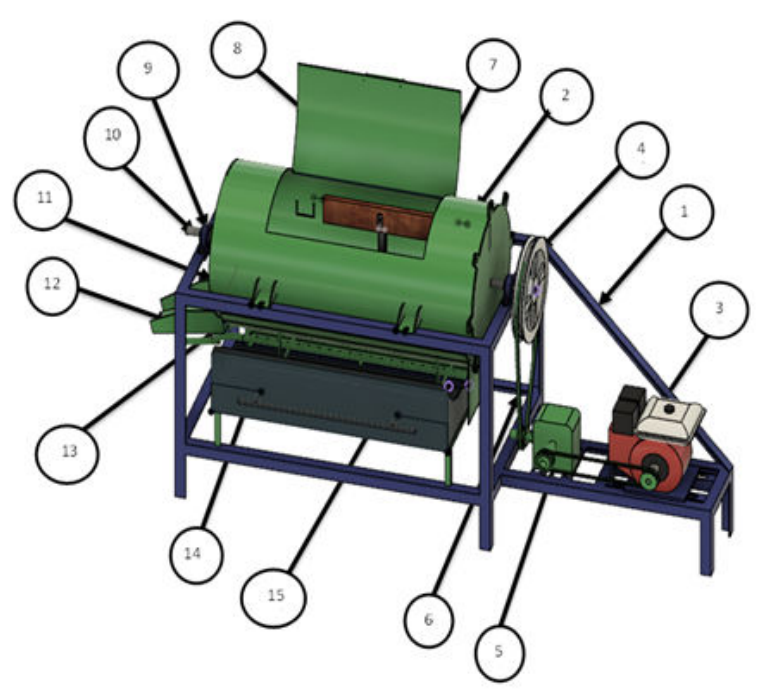

Figure 1. Design of grain dryer machine

Legend:

1. Frames

2. Cylinder tube

3. Drive motor

4. Pulley

5. Reducer

6. Belt

7. Stirrer

8. Cylinder door

9. Bearing

10. Shaft

11. Output

12. funnel

13. Tube lock

14. Stove

15. Burning rack

\section{Results and Discussion}

\section{A. Manufacturing Result}

The process of making the grain dryer machine was performed after going through the design process. The results of the design have provided the necessary data in the manufacturing process, namely the materials and tools used and the work process to be carried out, as shown in Table 1. The manufacturing result was shown in Figure 2. 
Table 1. Manufacturing process of grain dryer machine

\begin{tabular}{|c|c|c|c|c|}
\hline No. & Components & Tools & Materials & Manufacturing Process \\
\hline 1. & Main frame & $\begin{array}{l}\text { - Grinding machine, } \\
\text { - Welding machine } \\
\text { - Board marker } \\
\text { - PPE }\end{array}$ & $\begin{array}{c}\text { Elbow plate } 40 \\
\text { x } 40 \times 3 \mathrm{~mm}\end{array}$ & $\begin{array}{l}\text { - Measuring and cutting materials using a grinding } \\
\text { machine according to the size made } \\
\text { - Connecting the pieces of iron pipe using an } \\
\text { electric welding machine according to the } \\
\text { working drawings. } \\
\text { - Making a hole according to a predetermined } \\
\text { point using a hand drill with a drill bit size of } \\
12 \mathrm{~mm}\end{array}$ \\
\hline 2. & Dryer cylindrical & $\begin{array}{l}\text { - Hand drilling } \\
\text { machine } \\
\text { - Drill bit of M2 } \\
\text { - Plate rolling } \\
\text { machine } \\
\text { - Grinding machine, } \\
\text { - Welding machine } \\
\text { - Board marker } \\
\text { - PPE }\end{array}$ & $\begin{array}{l}\text { Plate steel (2 } \\
\text { mm), elbow } \\
\text { steel and steel } \\
\text { bar dia. } 6 \mathrm{~mm}\end{array}$ & $\begin{array}{l}\text { Measuring and cutting the iron plate according } \\
\text { to the size of the working drawings, } \\
\text { - Rolling the plate to form a circle, connecting the } \\
\text { two ends with a welding joint } \\
\text { - Making a hole using a hand drill with a diameter } \\
\text { of } 2 \mathrm{~mm} \text {, } \\
\text { - Installing the tube cover using welded joints and } \\
\text { bolts, } \\
\text { - Cutting on the cylinder and cylinder cover } \\
\text { - Installing the iron plate on the cylinder using a } \\
\text { welded joint, }\end{array}$ \\
\hline 3. & g shaft & $\begin{array}{l}\text { - } \text { Bench drilling } \\
\text { machine } \\
\text { - Drill bit M12 } \\
\text { - Welding machine } \\
\text { - Hand grinder } \\
\text { machine } \\
\text { - PPE }\end{array}$ & $\begin{array}{l}\text { Shaft with dia. } \\
30 \mathrm{~cm} \times 165 \\
\mathrm{~cm} \text {, wood, bolt } \\
\text { and hollow } \\
\text { steel }\end{array}$ & $\begin{array}{l}\text { - Cutting the shaft that has been measured with a } \\
\text { grinding machine, } \\
\text { - Cutting hollow iron that has been measured using } \\
\text { a grinding machine, } \\
\text { - Making holes in wood and hollow iron according } \\
\text { to the predetermined place points using a drill bit } \\
\text { with a drill bit size M12, } \\
\text { - Connecting hollow iron to the shaft using electric } \\
\text { welding, } \\
\text { - Installing wood in hollow iron using M12 bolts }\end{array}$ \\
\hline 9. & Burning $\mathrm{c}$ & $\begin{array}{l}\text { - Bench drilling } \\
\text { machine } \\
\text { - Welding machine } \\
\text { - Hand grinder } \\
\text { machine } \\
\text { - PPE }\end{array}$ & $\begin{array}{ll}\text { - } & \begin{array}{l}\text { Steel plate } \\
\text { (thickness }\end{array} \\
\text { of } 2 \mathrm{~mm} \text { ) } \\
\text { - } & \text { Steel pipe } \\
\text { dia. } 20 \mathrm{~mm}\end{array}$ & $\begin{array}{l}\text { - Cutting the iron plate with a grinding machine } \\
\text { according to the specified size, } \\
\text { - Cutting a steel pipe of } 68 \mathrm{~mm} \text { length with a } \\
\text { grinding machine, } \\
\text { - Connect the steel plate to the steel pipe using an } \\
\text { electric welding machine. } \\
\text { - Making holes in the steel pipe using a } 3 \mathrm{~mm} \text { drill } \\
\text { bit. }\end{array}$ \\
\hline
\end{tabular}




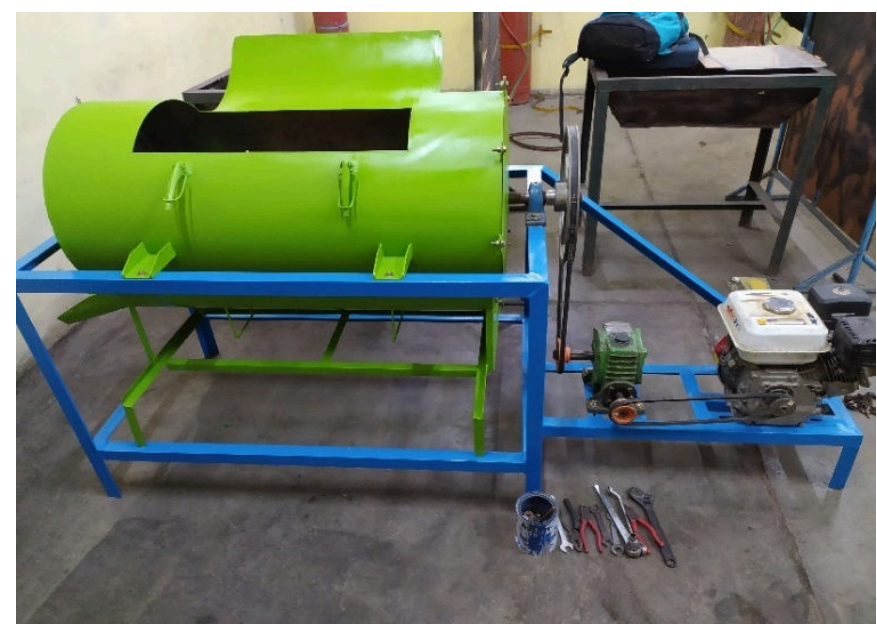

Figure 2. Manufacturing result of grain dryer machine

\section{B. Testing Result}

The process of testing the machine for data retrieval is carried out after the manufacturing process. Tests are carried out to determine the performance of the machine. The temperature used in data collection for heat sources from LPG gas cylinders is $57^{\circ} \mathrm{C}$ and for heat sources from coconut shells is $69^{\circ} \mathrm{C}$. The test was carried out in three stages for the same initial weight of grain and different time durations in order to obtain accurate data. Furthermore, the drying results can be seen from the final weight of the grain obtained. The test data obtained from the grain drying machine and can be seen in Table 2 .

Table 2. Testing results of grain dryer machine using fuel of LPG and

\begin{tabular}{|l|c|c|c|c|c|}
\hline No & $\begin{array}{c}\text { Initial } \\
\text { Weight } \\
(\mathrm{kg})\end{array}$ & $\begin{array}{c}\text { Final } \\
\text { Weight } \\
(\mathrm{kg})\end{array}$ & $\begin{array}{c}\text { Duration } \\
(\text { Minutes })\end{array}$ & $\begin{array}{c}\text { Drying } \\
\text { Temp. } \\
\left({ }^{\circ} \mathrm{C}\right)\end{array}$ & Fuel Type \\
\hline 1. & 30,6 & 29,23 & 45 & 57 & LPG \\
\hline 2. & 30,6 & 28,93 & 60 & 57 & LPG \\
\hline 3. & 30,15 & 28,40 & 20 & 69 & Coconut shell \\
\hline
\end{tabular}

\section{Discussion}

The grain drying machine is made to facilitate the grain drying process which is equipped with a control system and still uses solar heat. This machine is also designed and manufactured with the safety and comfort of the operator in mind so as to reduce the risk of work. The grain drying machine consists of various components, namely the engine frame, drying cylinder, shaft, stove, stirrer, and output funnel. The grain dryer machine has been made and assembled, then tested to determine the performance of the machine by using the engine power source comes from a gasoline motor with a power of $3 \mathrm{HP}$. This trial process was carried out 4 times to obtain accurate data.

The first test was carried out using $30.6 \mathrm{~kg}$ of grain with a fire setting on the stove and a temperature of $57^{\circ} \mathrm{C}$. In the first stage of testing, the drying time required is 45 minutes; the final weight is lower than the initial weight due to a decrease in water content with the final result of grain weight $29.23 \mathrm{~kg}$ and a decrease in grain weight of $1.37 \mathrm{~kg}$. The second test was carried out using $30.6 \mathrm{~kg}$ of grain with a fire setting on the stove and a temperature of $57^{\circ} \mathrm{C}$. In this test, the drying time required was 60 minutes, and it was found that the final weight was lower than the initial weight due to a decrease in water content with a final grain weight of $28.73 \mathrm{~kg}$ and a decrease in grain weight of $1.87 \mathrm{~kg}$. The third test was carried out using $30.15 \mathrm{~kg}$ of grain with coconut shell according to the test procedure and a temperature of $69^{\circ} \mathrm{C}$. In this test, the drying time required was 20 minutes, and it was found that the final weight was lower than the initial weight due to a decrease in water content with a final grain weight of $28.40 \mathrm{~kg}$ and a decrease in grain weight of $1.75 \mathrm{~kg}$.

Grain is considered good if the grain has undergone a drying process. The characteristics of good grain are the water content has decreased, the color is brownish, and the texture of the grains will be very different. Dry grain when pressed will be hard, while raw grain when pressed will feel soft. The difference between undried and dry grain can be seen in Figure 3. 


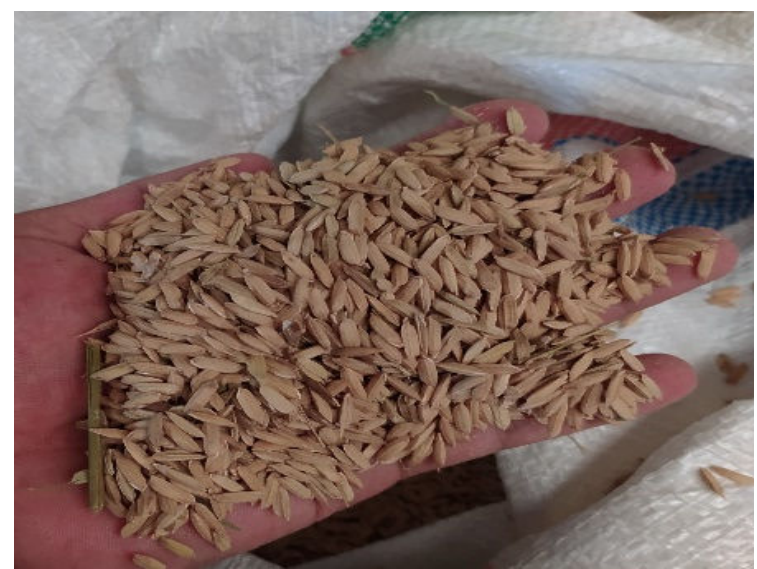

(a)

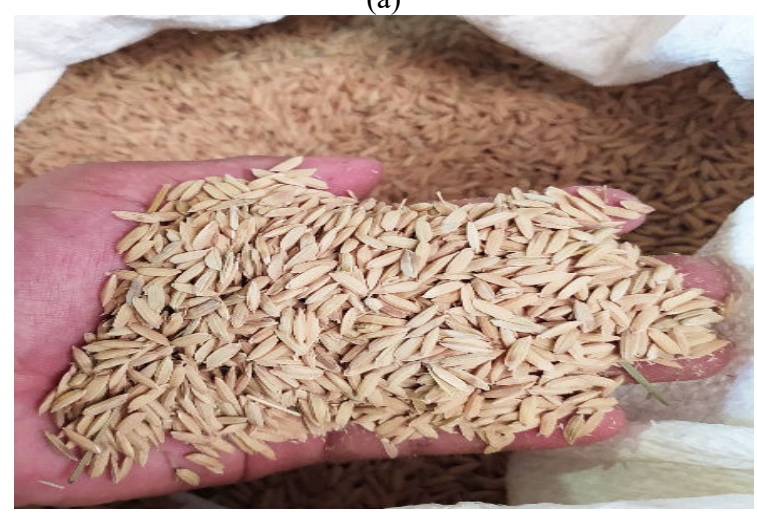

(b)

Figure 3. Appearance of grain before drying (a) and after drying (b) using a dryer machine

After doing 3 experiments, it can be stated that it takes 45 minutes to dry $30.6 \mathrm{~kg}$ of grain, 60 minutes for $30.6 \mathrm{~kg}$ of grain, and 20 minutes for $30.15 \mathrm{~kg}$ of grain. The results are quite satisfactory, and in the rainy season it will no longer be difficult to dry the grain. The grain drying process using coconut shell fuel obtained the best time for 20 minutes with a grain weight of $30 \mathrm{~kg}$. Furthermore, if the drying time is calculated for 1 hour of the grain drying process, then the dryer will be able to dry $90 \mathrm{~kg}$. The results of this drying can also minimize the drying time of the grain so that we conduct a more specific test using the measurement of the moisture content of the grain.

In order to ensure the desired test, the fourth test was carried out using $30.70 \mathrm{~kg}$ of grain with coconut shell according to the test procedure and a temperature of $67^{\circ} \mathrm{C}$. The drying time required is $10-15$ minutes with the moisture content of the grain in accordance with the logistics agency (BULOG) standard, which is 14-12 percent water content and is said to be dry. The result data was described in Table 3. The final weight was lower than the initial weight due to a decrease in water content with the final grain weight of $29.70 \mathrm{Kg}$ and a decrease in grain weight of $1 \mathrm{~kg}$.

Table 3. Test results of grain dryer machine using coconut shell fuel.

\begin{tabular}{|c|c|c|c|}
\hline No & $\begin{array}{c}\text { Drying Time } \\
\text { (Minute) }\end{array}$ & $\begin{array}{c}\text { Water content } \\
(\%)\end{array}$ & description \\
\hline 1 & 0 & 19,3 & Not yet dry \\
\hline 2 & 5 & 14,2 & Not yet dry \\
\hline 3 & 10 & 13,8 & dry \\
\hline 4 & 15 & 12,4 & dry \\
\hline
\end{tabular}

\section{Conclusion}

Based on the results of the design and manufacture of a grain drying machine, the following conclusions can be drawn that this grain dryer can simplify the process of drying grain for 6-7 hours/day if done manually. The grain dryer machine is able to dry up to $30 \mathrm{~kg}$ of grain and is able to minimize the drying time of grain to 10-20 minutes using coconut shell fuel and 30-60 minutes with LPG gas fuel.

\section{Acknowledgement}

Authors would like to thank Education, Culture, Research and Technology Ministry of Indonesia for funding this applied research through applied research scheme 2021-2023 with Contract Number: 261/E.4.1/AK.04.PT/2021.

\section{References}

[1] Y. Hayami, "Ecology, history, and development: A perspective from rural Southeast Asia," World Bank Res. Obs., Vol. 16, No. 2, pp. 169-198, 2001.

[2] M. D. Hammig, B. M. Shepard, G. R. Carner, R. Dilts, and A. Rauf, "Area-wide pest management for non-rice food crops in Southeast Asia," Area Wide Pest Manag. Theory Implementation, 2nd ed.; Koul, O., Cuperus, GW, Elliot, N., Eds, pp. 326-350, 2008.

[3] A. C. Chandra and L. A. Lontoh, Regional food security and trade policy in Southeast Asia: The role of ASEAN. Citeseer, 2010.

[4] T. E. Mafimisebi, B. O. Agunbiade, and O. E. Mafimisebi, "Price variability, co-integration and exogeniety in the market for locally produced rice: A case study of southwest zone of Nigeria,” J. Rice Res., Vol. 2, No. 1, pp. 1-6, 2014. 
[5] G. L. Cramer, J. M. Hansen, and E. J. Wailes, "Impact of rice tariffication on Japan and the world rice market," Am. J. Agric. Econ., Vol. 81, No. 5, pp. 1149-1156, 1999.

[6] T. Panggabean, A. N. Triana, and A. Hayati, "Kinerja pengeringan gabah menggunakan alat pengering tipe rak dengan energi surya, biomassa, dan kombinasi", (Grain drying using a rack-type dryer with solar energy, biomass, and a combination), Agritech, Vol. 37, No. 2, pp. 229-235, 2017.

[7] R. Nur and M. A. Al Banjari, "Efektifitas alat pengering tipe box gabah padi (Oryza Sativa L.) terhadap tingkat kadar air", (The effectiveness of the rice grain box type dryer (Oryza Sativa L.) on the level of water content), Turbo J. Progr. Stud. Tek. Mesin, Vol. 9, No. 1, 2020.

[8] D. Yogendrasasidhar and Y. P. Setty, "Drying kinetics, exergy and energy analyses of Kodo millet grains and Fenugreek seeds using wall heated fluidized bed dryer," Energy, Vol. 151, pp. 799-811, 2018.

[9] S. Syahrul, M. Mirmanto, Y. Hartawan, and S. Sukmawaty, "Effect of air intake temperature on drying time of unhulled rice using a fluidized bed dryer," Heat Mass Transf., Vol. 55, No. 2, pp. 293-298, 2019.

[10] S. Yunus, M. Anshar, I. Marzuki, N. Anggraini, F. Ariani, and R. Ramdiana, "Pemanfaatan Sekam Padi Sebagai Bahan Bakar Alat Pengering Gabah di Kelurahan Allepolea Kec Maros Baru Kabupaten Maros", (Utilization of Rice Husk as Fuel for Grain Dryer in Allepolea Village, Maros Baru District, Maros Regency), in Seminar Nasional Hasil Penelitian \& Pengabdian Kepada Masyarakat (SNP2M), pp. 181-186. 2020.

[11] H. Hariyanto, M. Rusdi, C. A. Wahyudhi, and A. Andriyono, "Aplikasi Teknologi Pengering Padi (Rotary Driyer) Kapasitas 2 Ton dengan Bahan Bakar Sekam Padi”, (Application of Rice Dryer Technology (Rotary Driyer) Capacity of 2 Tons with Rice Husk Fuel), MUSTEK ANIM HA, Vol. 9, No. 03, pp. 120-124, 2020.

[12] L. S. Kjær, M. Poulsen, K. Sørensen, and T. Condra, "Modelling of hot air chamber designs of a continuous flow grain dryer," Eng. Sci. Technol. an Int. J., Vol. 21, No. 5, pp. 1047-1055, 2018. 